\title{
ПРОБЛЕМИ НАДАННЯ МЕДСЕСТРИНСЬКОЇ ДОПОМОГИ ХВОРИМ ІЗ ПОРУШЕННЯМ МОЗКОВОГО КРОВООБІГУ В ВІДДІЛЕННЯХ НЕВРОЛОГІЧНОГО ПРОФІЛЮ
}

\author{
О. В. Майборода, О. Л. Сидоренко \\ КЗ «Запорізька центральна районна лікарня" \\ ДвНЗ «Тернопільський держсавний медичний університет \\ імені І. Я. Горбачевського МОЗ Украӥни»
}

У статті проаналізовано проблеми медсестринського процесу в лікуванні пацієнтів із порушенням мозкового кровообігу; визначено необхідність розробки і впровадження протоколу медичної сестри щодо обстеження пацієнта з даною патологією.

\section{PROBLEMS OF NURSING CARE FOR PATIENTS WITH IMPAIRED CEREBRAL CIRCULATION UNDER THE CONDITIONS OF NEVROLOGIC DEPARTMENT}

\author{
O. V. Maiboroda, O. L. Sydorenko \\ Zaporizhzhia Central District Hospital \\ I. Horbachevsky Ternopil State Medical University
}

The article analyzes the problems of nursing care in treatment of patients with impaired cerebral circulation. It defines the necessity of development and implementation of special nursing protocol according to examination of a patient with this disorder.

Вступ. За даними Всесвітньої організації охорони здоров'я (ВООЗ), 17,3 млн людей у всьому світі щороку переносять інсульт.

Інсульт залишається другою за частотою причиною смерті (12 \% усіх смертей) і провідною причиною інвалідизації у світі. Прогнозована смертність від інсульту в світі до 2030 р. становитиме 7,8 млн осіб. В Україні лише у 2016 р. інсульт перенесли 97805 людей, з них 33 \% - працездатного віку [1].

Після перенесеного інсульту третина хворих помирає протягом першого року і ще близько третини назавжди залишається залежною від сторонньої допомоги. Інсульт і його соціально-економічні наслідки становлять настільки серйозну загрозу добробуту населення земної кулі, що в більшості розвинутих країн профілактика та лікування цереброваскулярної патології офіційно визнані пріоритетними завданнями охорони здоров'я.

Основна частина. В розвинутих країнах структурною одиницею системи допомоги пацієнтам 3 інсультом $\epsilon$ спеціалізований інсультний центр, або

(с) О. В. Майборода, О. Л. Сидоренко, 2018 інсультні відділення/блоки, що в англомовній літературі отримали назву «StrokeUnit». У «StrokeUnit» забезпечується лікування та реабілітація хворих з інсультом, починаючи з найгострішого періоду, зусиллями компетентної мультидисциплінарної команди відповідно до протоколів, створених на основі доказової медицини.

В Україні у 2002 р. наказом МОЗ України від 30.07.2002 р. № 297 «Про вдосконалення медичної допомоги хворим з цереброваскулярною патологією» затверджено створення інсультних відділень (центрів). Кількість ліжок у даних центрах відповідно до цього наказу розраховують як 5-7 на 300 тис. населення. Інсультні відділення, або центри, створені переважно на базі багатопрофільних лікувальних закладів у обласних центрах. Кількість ліжок в інсультних відділеннях різних регіонів становила від 15 до 60 [2]. Недостатній ліжковий фонд - це одна з причин, чому лише 53-73 \% хворих на інсульт проходять лікування у спеціалізованих центрах.

Термін перебування в інсультних відділеннях складає 3-5 діб, далі хворі переводяться у відділення 
судинної патології або загальноневрологічні відділення згідно з показаннями [3]. Також у неврологічні відділення за місцем проживання госпіталізовують пацієнтів, які не потрапили до високоспеціалізованих відділень через нестачу ліжок.

З 2012 р. в Україні впроваджено клінічні рекомендації «Ішемічний інсульт» та «Реабілітація, профілактика і лікування ускладнень та планування виписки при ішемічному інсульті», уніфіковані клінічні протоколи медичної допомоги (УКПМД) «Ішемічний інсульт» і «Системний тромболізис при ішемічному інсульті» (наказ МОЗ України від 03.08.2012 р. № 602), а з 2014 р. - клінічне керівництво «Аневризматичний субарахноїдальний крововилив» та УКПМД «Геморагічний інсульт» (наказ МОЗ України від 17.04.2014 р. № 275).

Ці настанови розроблені на основі європейських та світових стандартів надання допомоги та передбачають великий обсяг досліджень і медичних втручань. обов'язкова умова успішної роботи інсультного відділення - достатній штат медичного персоналу для забезпечення адекватного спостереження та догляду за кожним пацієнтом. Але в загальноневрологічних відділеннях навантаження на одну медичну сестру за зміну складає від 15 до 50 пацієнтів. Порівняємо, наприклад, у Швеції та Італії в інсультних центрах на 10 пацієнтів доводиться від 3 до 5 медичних сестер на одну зміну. Таким чином, велика кількість пацієнтів та сестринських втручань, величезний обсяг паперової документації, що припадає на наших медичних сестер унеможливлює ведення на належному рівні сестринського процесу.

Медсестринська допомога зосереджується на загальних потребах хворих і їх сімей та включає фізичну, психологічну, когнітивну, емоційну, духовну і соціальну допомогу. Медсестра розглядає потреби особистості разом із пацієнтом та членами його сім'ї, щоб залучити їх до прийняття рішень і відновлення пацієнта. Здійснення сестринського догляду за хворим на інсульт $\epsilon$ безперервним 24-годинним процесом

\section{СПИСОК ЛІТЕРАТУРИ}

1. Стасенко Т. Інсульт: впровадження успішних стратегій лікування [Електронний ресурс] / Т. Стасенко // Український медичний часопис. - 2017. - Режим доступу до ресурсу : http://www.umj.com.ua/article/117650/insultvprovadzhennya-uspishnih-strategij-likuvannya

2. Чи можлива в Україні європейська модель медичної допомоги при інсульті? [Електронний ресурс]. - Режим протягом усього маршруту пацієнта, де надають медичну допомогу [4].

Для здійснення адекватного моніторингу стану пацієнта та динаміки захворювання необхідно насамперед провести повноцінне обстеження пацієнта з урахуванням не тільки вітальних функцій, можливості самостійного дихання, ковтання (щоденного проведення скринінгу дисфагії), стану шкіри, можливих порушень мовлення, когнітивних функцій, визначення адекватного типу харчування, необхідності встановлення периферичних та сечових катетерів [5]. Медична сестра має розрізняти пролежні та інші види ран (венозні, артеріальні чи нейропатичні виразки, розриви шкіри, інтертриго), а також належним чином використовувати класифікацію пролежнів різної локалізації, оцінювати ризик пролежнів (за шкалою Браден) та документувати результати оцінювань [6].

Задля забезпечення наступності отриманої інформації потрібно задокументувати отримані клінічні дані, проведені додаткові втручання та зроблені висновки. На даний час стандартизованою формою для внесення даних медичною сестрою про стан пацієнта $є$ температурний лист. Але цей документ ніяк не відповідає поставленим вимогам. Тож, за умов нестачі часу в медичної сестри та наявності великої кількості проблем у пацієнта, що потребує постійного моніторингу, одним із рішень проблеми може бути розробка нової форми медичної документації для внесення отриманої інформації.

Висновки. Складність та можливість швидкої зміни стану пацієнта з інсультом, великий обсяг залежних та незалежних сестринських втручань потребує розробки та впровадження протоколів медичної сестри щодо оцінки стану пацієнта з порушенням мозкового кровообігу та стандартизації догляду за хворими 3 цією патологією. Необхідною $є$ розробка нової форми документації для медичної сестри, що допоможе вчасно систематизувати отриману інформацію та зробити відповідні висновки задля покращення загального стану пацієнта.

доступу до ресурсу : http://www.vz.kiev.ua/chi-mozhliva-vukrayini-yevropejska-model-medichnoyi-dopomogi-pri-insulti/

3. Про вдосконалення медичної допомоги хворим 3 цереброваскулярною патологією : наказ МОЗ України від 30.07.2002 р. № 297. - К., 2002.

4. Реабілітація, профілактика і лікування ускладнень та планування виписки при ішемічному інсульті : адап- 
тована клінічна настанова, основана на доказах. - К., 2012. - С. 102-110.

5. Сара Д. С. Мозковий інсульт: догляд за хворими [Електронний ресурс у перекладі із італ.] / Di Santo Sara. Ictus Cerebrale assistenza infermieristica al paziente //
«Nurse24.It». - 2017. - Режим доступу до ресурсу : https:// www.nurse24.it/studenti/dispense-e-piani-assistenziali/ ictus-cerebrale-assistenza-infermieristica-al-paziente.html 6. Гострі порушення мозкового кровообігу. Ішемічний інсульт: Уніфікований клінічний протокол медичної допомоги. - К., 2012. - С. 28-40.

Отримано 08.02.18 